\title{
Distributian of Depth and Clay-Silt to Sand Ratio of Land Subsidence in Coastal Semarang City by Resistivity Methods
}

\section{Sugeng Widada $13^{*}$, Muhammad Zainuri1,3, Gatot Yulianto ${ }^{1,2}$ Sidhi Saputra ${ }^{3}$ and Baskoro Rochaddi 3}

\author{
1Doctorate Program of Marine Science, Faculty of Fisheries and Marine Sciences, Diponegoro \\ University \\ 2Department Physic, Faculty of Science and Mathematics, Diponegoro University \\ ${ }^{3}$ Department Oceanography, Faculty of Fisheries and Marine Sciences, Diponegoro University \\ Jl. Prof. H. Soedharto, SH., Tembalang, Semarang, Indonesia 50275
}

Email: swidada1@gmail.com

\begin{abstract}
Semarang City is the capital of Central Java province, located in the northern coast of Java island, Indonesia which is geologically composed of alluvial deposits. The natural consolidation of young alluvial deposits has caused a land subsidence. On the other hand, load of buildings and constructions causes an increase in the pressure of land surface, and finally, leads to an increase in the rate of land subsidence. The drilling data indicated that not all layers of lithology are soft layers supporting the land subsidence. A research on the depth of soft litology and its percentage of hard lithology has not been conducted ever before. On the other side, an analysis regarding this kind of research can be conducted based on resistivity method. Sounding system method with Schlumberger electrode configuration was selected for field data collection. The goals of this research were to determine the resitivity of lithology so that it can be used to interpretate distribution of depth and clay-silt to sand ratio of land subsidence area. The results showed that the area with the depth of the upper layer of clay-silt less than $3 \mathrm{~m}$ and clay-silt to sand ratio less than 4 were the high land subsidence area.
\end{abstract}

Keywords: Land subsidence, Semarang, Resistivity

\section{Introduction}

Semarang is one of the the capital of Central Java province and nowadays suffering from extended land subsidence. Land subsidence, as a movement of a surface downwards relative to a datum such as sea level, is a major constraint to the development in many refions all over the world. As the effect of the land subsidence, some areas have been in below the sea level so it will be flooded with coastal flooding (rob) (Marfai and King, 2007). It can damage existing buildings, roads, bridges, industrial estates, and results in loss of homes, so it results in disturbing the activity of the people. The handling of this situation has been managed to be conducted by arranging the function of the area by paying attention to all behaviors of land subsidence, but it is not completely succeed yet.
The research on land subsidence rate in Semarang city has been carried out by experts and shows that there was a difference between one place and another. Based on the estimation from Levelling, Interferometric Synthetic Aperture Radar (InSAR), Microgravity and Global Positioning System (GPS) survey methods, land subsidence with rates of up to about $19 \mathrm{~cm} /$ year were observed during the period of 1999 up to 2011 (Gumilar et al., 2013). That rate of land subsidence was affected by the process of alluvial consolidation and added by the exploitation of overflowing ground water and the building construction in some points (Abidin et al., 2010; 2012). Tectonic activity is not related to the land subsidence so that the bedrock does not decrease (Wardhana et al., 2014) The effect of land subsidence is predicted to cause the flooded area increases from $2,162.5 \mathrm{Ha}(5.6 \%)$ to $3,896.3 \mathrm{Ha}(10.1 \%)$ in the 
2012 up to 2022 (Suhelmi. 2012). The rate of land subsidence in Semarang City is generally getting higher in the location with the thickness of soft lithology layer detected as the lithology with resistivity < ohm (Widada et al., 2017a). Eventhough, it was not yet explained the other lithology in the layer system and it's distribution which is contributing in the land subsidence.

This research aimed to map the lithology layer system which resulting in the land subsidence by identifying thickness comparation of clay-silt and sand and also the cover layer thickness of the soft lithology layer and mapping the spread spatially according to the data of resistivity measurement.

\section{Materials and Methods}

Resistivity method is measurement technique of geophysics that uses resistivity or electicity characteristic of rocks to observe subsurface of earth condition (Widada et al., 2017a). Measuerment was conducted in the land surface by injecting electricity current (in miliAmpere) along two current electrodes (C1 and $\mathrm{C} 2$ ) then gaining potential difference (in miliVolts) from two potential electrodes (P1 and P2). There is positive connection between rare electrode with the current penetration into the earth. The widest electrodes space could be get a depth currecnt penetration, hence the physical characteristics of deeper rock layer can be analyzed (Setyawan et al., 2016). The location points of resistivity measurement can be seen in Figure 1.

In the field implementation using Schlumberger configuration (Dobrin, 1976). The distance of the electrode was arranged so that $R 1=R 4=(b-1 / 2 a)$ and $R 2=R 3=(b+$ $1 / 2 \quad a)$, where $a$ is the distance between the two potential electrode and $b$ is the distance of the center point to the current electrode (Figure 2). In this state, the range of potential electrode P1 - P2 is started from 1/3 of range of the current electrode $\mathrm{Cl}-\mathrm{C} 2$. Furthermore, the measurement was done by only moving the current electrode to a distance where the measurement result of the potential difference P1 - P2 is already small, then $\mathrm{Pl}-\mathrm{Pl}$ is extended step by step.

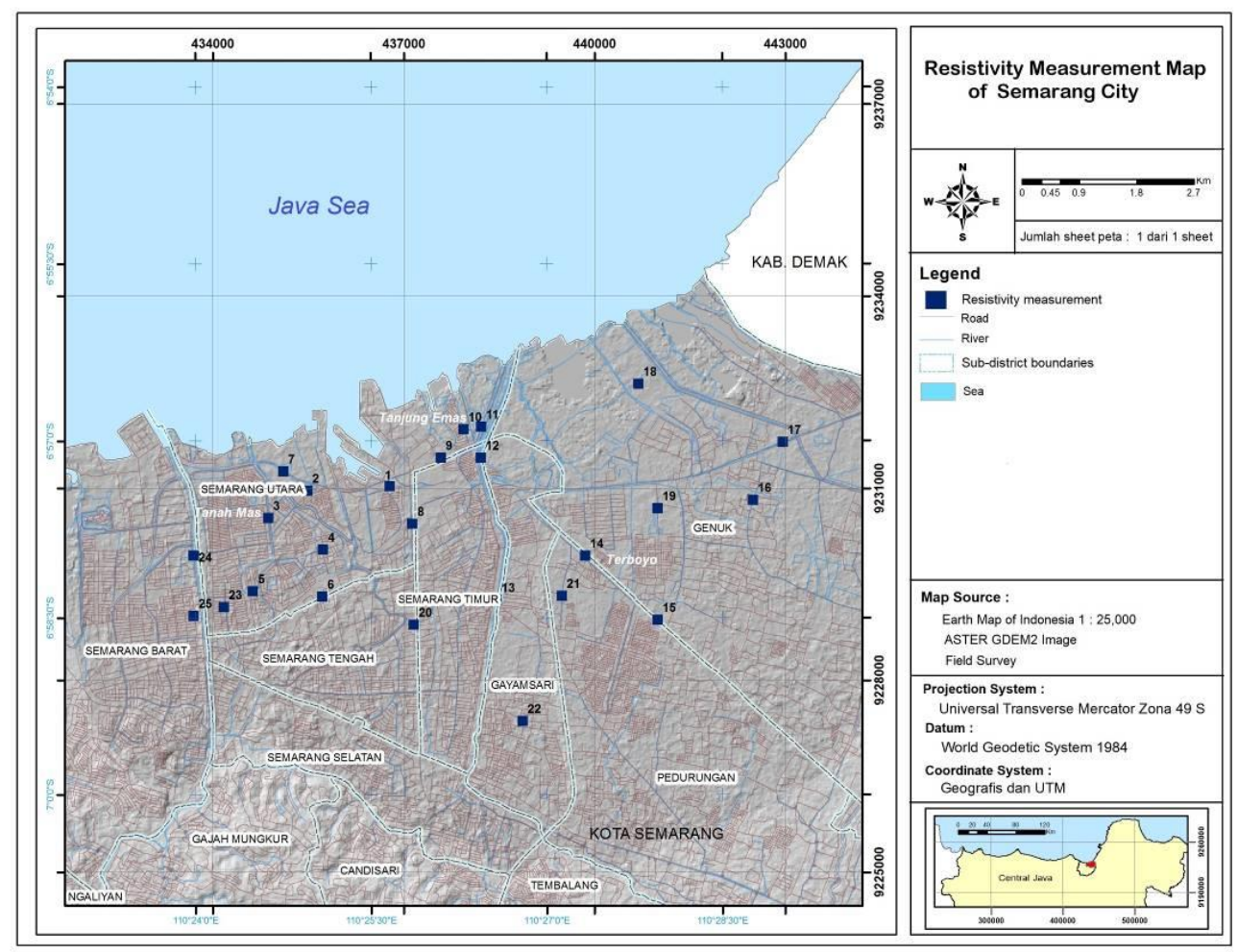

Figure 1. Resistivity measurement map 


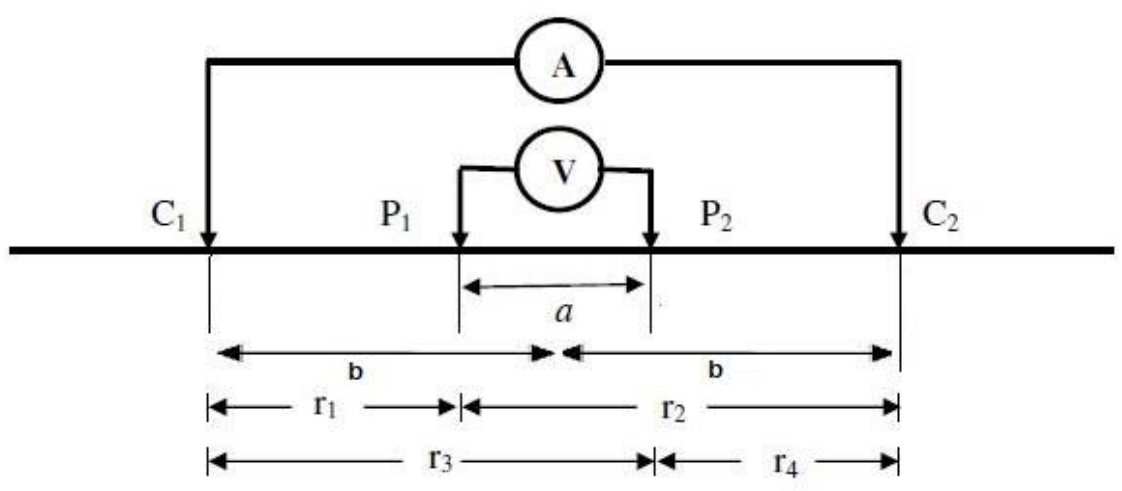

Figure 2. The scheme of electrode arrangement of Shclumberger configuration (Dobrin, 1976)

The field data obtained from the resitivity measurement were the distance of current electrode, distance of potential electrode, current (i), and the potential difference $(\Delta \mathrm{V})$. The resistivity of the medium was calculated frome the quotient of the $\Delta \mathrm{V} / \mathrm{l}$ using a modified Ohm's law. Based on the data, the apparent resistivity was measured for every current injection, so the value of apparent resistivity was obtained for every electrode spread. The graph of the spacing electrode and the apparent resistivity then were used as the basic in determining the thickness and the true resistivity by using the Ip2Win software. The results obtained were the thickness and the resistivity of every lithology layer (Widada et al., 2017a)

The resistivity for every lithology layer that was obtained in the data processing, was then interpreted the type of lithology by referring to the resistivity of lithology type from the references and correlated to the type of lithology based on the geotechnical drilling data. In the geotechnical drilling data, besides the description of the type of lithology, also listed the physical characteristics of lithology related to it's ability to accept the burden, so it could be interpreted the behaviors of lithology related to the land subsidence. From the interpretation result in every point of resistivity measurement, a contour map was made to depict the depth of soft lithology/clay and silt) layer which causes the land subsidence in the research area. Comparison of clay-silt thickness to sand which has a greater bearing capacity was also analyzed to get an overview of its influence on land subsidence.

\section{RESULT AND DISCUSSION}

Based on Semarang and Magelang Geological Map (Thanden et al., 1996) Semarang has three main lithologies, namely, volcanic rock, sedimentary rock, which is marine in origin, and alluvial deposits.Volcanic rock consists of volcanics breccias, lava flow, tuff, sandstone, and clay stone. This area is located on the Southern part of Semarang. Sedimentary rock originated from marine consists of clay stone and dominated by sandstone in between. Alluvial sediment consists of beach deposits formed by clay and sand with a thickness of more than $80 \mathrm{~m}$ with the age of the Holocene period. It is on these deposits (Marin sediment and alluvial sediment) where the land subsidence is occurring. The layer of clay and silt will prone to have smaller resistivity than the sand, especially if it contains water (Yulianto et al., 2016). Resistivity of clay and silt in Semarang alluvial deposits was about less than $3 \mathrm{ohm}$, while sand resistivity ranges from $5-20 \mathrm{ohm}$ (Widada et al., 2017b). Based on this criterion, the results of the depth of clay-silt layer and comparasion the thickness of clay-slit to the thickness of sand (clay-slit to sand ratio) were presented in Table 1. In this table, each resistivity measurement point pairing with the data of land subsidence measurement (Wardhana et al., 2014).

The map of land subsidence overlayed by the map of depth of top soft layer clay-silt is presented on Figure 3. Based on the figure, it can be seen that the rate of land subsidence at the location around Tanah Mas, Tanjung Emas Port and Terboyo are higher than another areas (brown and red 
color). In these areas, depth of top soft layer are less than another areas (shaded vertical and horizontal line). This pattern indicates that the thinner layer of the soft layer covers, then the burden of the building on it rests directly on the soft layer. Large pressure on the soft layer enlarges compression and increases in land subsidence.

The location around Tanjung Emas Port and Tanah Mas in North Semarang Subdistrict had the higher land subsidence than the other areas at $9.4-10.08 \mathrm{~cm} /$ year. In that location, it was found that the depth of soft layer was also less than another areas at 1.0 $1.5 \mathrm{~m}$ in Tanah Mas and $0.9-1.0 \mathrm{~m}$ in around Tanjung Mas Port. In the point 23 of resistivity measurement located in Krobokan with the land subsidence of $10.69 \mathrm{~cm} /$ year also had the depth of soft layer about $4.0 \mathrm{~m}$. The location with a slightly higher rate of land subsidence was also found in around Terboyo, at $8.58 \mathrm{~cm} / \mathrm{year}$, and it actually had the depth of soft layer for $2.3 \mathrm{~m}$. The spread of soft layer can be found in all research areas with the depth varied $0.9 \mathrm{~m}$ to $10.8 \mathrm{~m}$.

The map of land subsidence overlayed by clay-silt ratio is presented on the Figure 4 . Based on the figure, it can be seen that the rate of land subsidence in the location around Tanah Mas, Tanjung Emas Port and Terboyo are higher than another areas (brown and red color). Generally, clay-silt to sand ratio in this area are less than another areas (shaded vertical and horizontal line). This pattern indicates the sand layer plays a role in minimizing land subsidence. A high land subsidence is actually happening in the thick soft layer. It happened because that

Table 1. The Depth of soft lithology layer, clay-slit to sand ratio based on the resistivity data and the rate of land subsidence in Semarang City

\begin{tabular}{lccccc}
\hline Point No. & East & North & $\begin{array}{c}\text { Depth of Soft } \\
\text { Lithology layer }(\mathrm{m})\end{array}$ & $\begin{array}{c}\text { Clay-Silt To Sand } \\
\text { Ration }\end{array}$ & $\begin{array}{c}\text { Rate of land } \\
\text { subsidence } \\
\text { (cm/year) }\end{array}$ \\
\hline $\mathbf{1}$ & 433697 & 9229943 & 8.0 & 1.273 & 5.77 \\
2 & 435485 & 9230954 & 1.5 & 1.698 & 3.50 \\
3 & 434868 & 9230527 & 3.0 & 4.241 & 5.28 \\
4 & 435731 & 9230038 & 5.7 & 2.106 & 8.51 \\
5 & 434629 & 9229383 & 1.0 & 3.137 & 10.69 \\
6 & 435719 & 9229303 & 9.7 & 0.307 & 0.47 \\
7 & 435105 & 9231261 & 1.0 & 1.873 & 9.90 \\
8 & 437136 & 9230440 & 1.0 & 1.618 & 3.50 \\
9 & 437583 & 9231474 & 1.0 & 1.134 & 10.45 \\
10 & 437942 & 9231918 & 4.0 & 17.228 & 3.50 \\
11 & 438217 & 9231957 & 0.9 & 0.414 & 10.45 \\
12 & 438215 & 9231470 & 1.0 & 0.712 & 7.00 \\
13 & 438464 & 9229248 & 6.2 & 1.499 & 5.00 \\
14 & 439857 & 9229941 & 6.6 & 0.357 & 5.09 \\
15 & 440994 & 9228939 & 10.9 & 2.447 & 8.81 \\
16 & 442496 & 9230815 & 11.8 & 1.308 & 8.58 \\
17 & 442960 & 9231722 & 2.2 & 0.347 & 5.76 \\
18 & 440693 & 9232628 & 2.2 & 12.871 & 4.02 \\
19 & 440992 & 9230686 & 3.3 & 0.541 & 7.00 \\
20 & 437161 & 9228864 & 4.0 & 0.099 & 5.09 \\
21 & 439486 & 9229312 & 4.5 & 1.729 & 10.69 \\
22 & 438870 & 9227356 & 5.2 & 0.608 & 9.90 \\
23 & 434170 & 9229137 & 4.0 & 0.445 & 0.50 \\
24 & 433697 & 9229943 & 3.0 & 0.570 & 1.273 \\
25 & 433697 & 9229000 & 8.0 & & \\
\hline
\end{tabular}




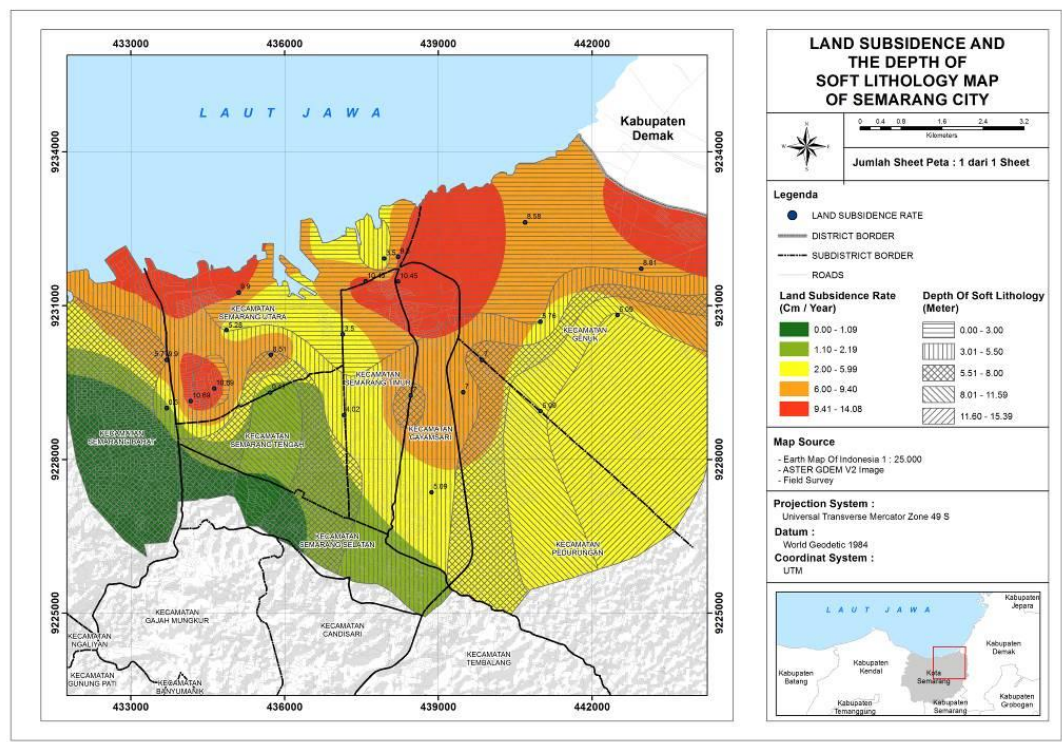

Figure 3. Map of the land subsidence and the depth of soft lithology in Semarang City

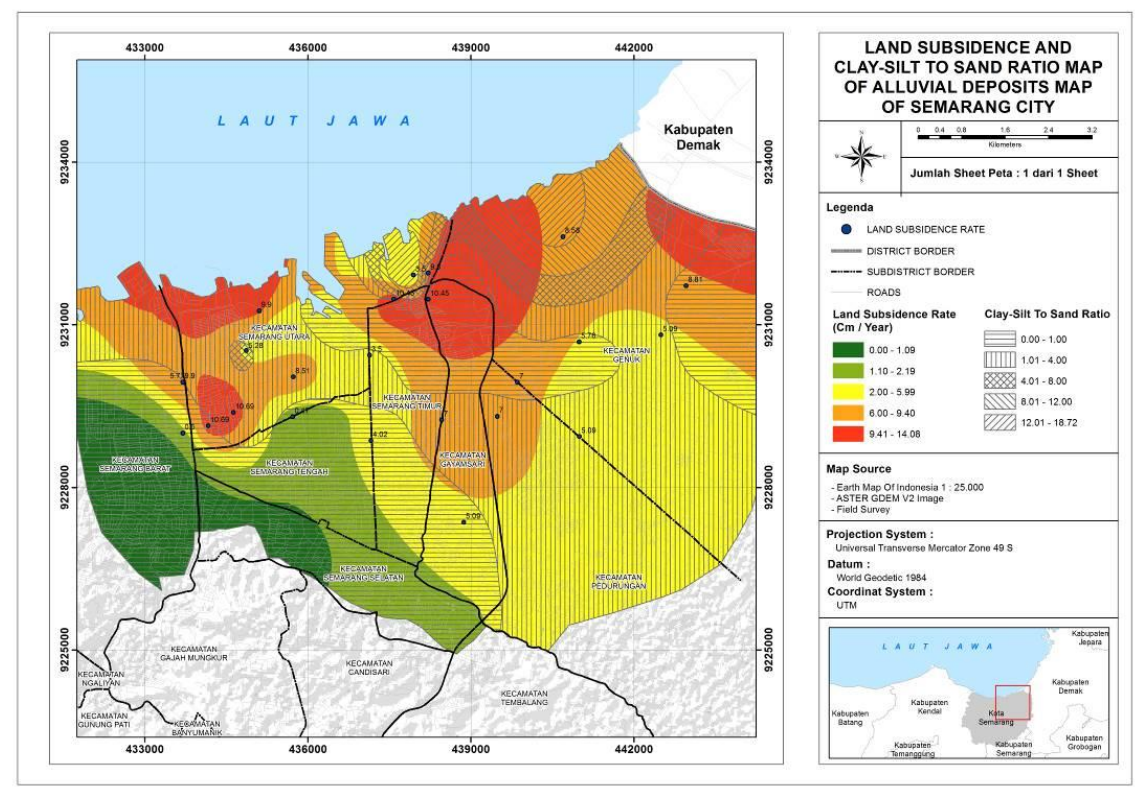

Figure 4. Map of the land subsidence and the clay-silt to sand ratio in Semarang City

soft layer is compressed when given the load from the above layer or from several buildings and infrastructures above the ground (Gumilar et al., 2013; Abidin et al., 2012). The consolidation process in the alluvial deposit is natural and surely happen (Reddish and Whittaker, 1989). Figure 4, also shows that there are an anomalies from the general pattern, namely in the eastern area of Tambaklorok to Terboyo, high clay-silt to sand ratio coincides with high land subsidence area. This is possible because in that location a thick soft layer is close to the surface, so the presence of sand layers is less able to play a role in reducing land subsidence

\section{CONCLUSION}

The rate of land subsidence in Semarang City is generally greater in areas with a small depth of soft layer. The small depth of soft layer in Tanah Mas, Tanjung 
Emas Port and the area around Terboyo were about $0.9-2.3 \mathrm{~m}$, and the rate of land subsidence was about $9.4-10.08 \mathrm{~cm} /$ year, higher than other areas. On the other hand, clay-to silt ratio in this area was 1,0 - 1,5 less than the another area. The anomaly shown in Tambaklorok-Terboyo area, areas with large land subsidies coincide with large silt to sand ratio. In this area thick soft layer is close to the surface, so the presence of sand layers is unable to play a role in reducing land subsidence.

\section{ACKNOWLEDGEMENT}

We would like to thank for any supports given by colleagues from Department of Oceanography Diponegoro University who have assisted in data measurement, processing until result discussion. This Research has supported by Non APBN Faculty of Fisheries and Marine Science, Diponegoro University, fiscal year 2018.

\section{REFERENCES}

Abidin, H.Z., Andreas, H., Gumilar, I., Sidiq, T.P., \& Fukuda, Y. 2012. Land subsidence in coastal city of Semarang (Indonesia): characteristics, impacts and causes. Geomatics, Natural Hazards and Risk, 4(3):226 - 240

Abidin, H.Z., Andreas, H., Gumilar, I., Sidiq, T.P., Gamal, M., Murdohardono, D., Supriyadi \& Fukuda, Y. 2010. Studying Land Subsidence in Semarang (Indonesia) Using Geodetic Methods. Procceding FIG Congress. Sydney, Australia. pp 1-15

Dobrin, M.B., 1976. Introduction to Geophysical Prospecting. Mc Graw-Hill, New York

Gumilar, I., Abidin, H.Z., Sidiq, T.P., Andreas, H., Maiyudi, R., Gamal, M. \& Fukuda, Y. 2013. Mapping And Evaluating The Impact Of Land Subsidence In Semarang (Indonesia). Ind. J. Geospat. 2(2):26-41
Marfai, M.A. \& King, L. 2007. Monitoring land subsidence in Semarang, Indonesia. Environ. Geol. 53:651-659

Reddish, D.J. \& Whittaker, B.N. 1989. Subsidence, Vol. $571^{\text {st }}$ Ed. Elsevier Science.

Setyawan, A., Najib, Aribowo, Y., Trihadini, A., Hastuti, D., Ramdhani, F., Waskito, F., Febrika G., \& Virgiawan, G. 2016. Sea Water Intrusion in Kaligawe Semarang Based on Resistivity Data. IOP Conf. Series : Earth Environmnet. Sci. 55(2017):012053.

Suhelmi. 2012. Kajian Dampak Land Subsidence Terhadap Peningkatan Luas Genangan Rob Di Kota Semarang. Jurnal Ilmiah Geomatika 18(1):9-16

Thanden, R.E., Sumadirdja, Richards, P.W., Sutisna, K., \& Amin, T.C. 1996. Geological Map Of The Magelang And Semarang Sheets Jawa. Second Edition (Bandung: Geological Research and Development Centre)

Wardhana, D.D., Harjono, H. \& Sudaryanto. 2014. Struktur Bawah Permukaan Kota Semarang Berdasarkan Data Gaya Berat. Riset Geologi dan Pertambangan 24(1):53-64.

Widada, S., Saputra., S., \& Hariadi. 2017. Determination of Soft Lithology Causes The Land Subsidence in Coastal Semarang City by Resistivity Methods. IOP Conf. Series : Earth Environmnet. Sci. 116(2018):012092

Widada, S., Satriadi, A. \& Rochaddi, B. 2017. Kajian Potensi Air Tanah Berdasarkan Data Geolistrik Resistiviti Untuk Antisipasi Kekeringan di Wilayah Pesisir Kangkung, Kabupaten Kendal, Provinsi Jawa Tengah, J. Kel. Trop. 20(1):35 - 41

Yulianto, T., Gernowo, R. \& Krisna, W. 2016. The determination of slip surface layer in Trangkil settlement area, Sukorejo Village, Gunungpati District, Semarang Municipality using two dimensional resistivity method with dipole-dipole configuration. Int. J. App. Environment. Sci. $11(6): 1363-1373$ 